\title{
Inhibition of Receptor-Dependent and Receptor-Independent Generation of the Respiratory Burst in Human Neutrophils and Monocytes by Human Serum IgA
}

HERMANN M WOLF, ERICH VOGEL, MICHAEL B. FISCHER, HENRI RENGS 1 HANS-PETER SCHWARZ, AND MARTHA M. EIBL

Institute of Immunology, University of Vienna /H.M.W., E.V., M.B.F., M.M.E./, and Immuno AG (H.R., H.-P.S./, Vienna, Austria

\section{ABSTRACT}

\begin{abstract}
An important feature of the role of $\operatorname{IgA}$ in protection against infection and disease at the level of the mucosal surfaces might be the elimination of pathogens without induction of a strong inflammatory reaction. In the present study we addressed the question whether $\operatorname{IgA}$ has a regulatory effect on the generation of reactive oxygen intermediates in human neutrophils and monocytes (i.e. the respiratory burst). Cells were stimulated with heat-inactivated Haemophilus influenzae type b or phorbol myristate acetate, stimuli known to use different recognition structures or signal transduction pathways. Concentrations of $\operatorname{IgA}$ as low as $10 \mathrm{mg} / \mathrm{L}$ significantly inhibited the receptordependent Haemophilus influenzae-induced respiratory burst in granulocytes, as assessed by measuring luminolenhanced chemiluminescence. Furthermore, $\operatorname{IgA}$ had a dose-dependent inhibitory effect on the receptor-independent induction of the respiratory burst, as examined by flow cytometry in monocytes and granulocytes activated with phorbol myristate acetate. Our results therefore indicate that inhibition of receptor-ligand interaction is not a sufficient explanation for the $\operatorname{IgA}$-mediated modulation of the respiratory burst in human phagocytic cells. In addition, IgA might directly regulate the activation of the respiratory burst at the level or downstream of protein kinase
\end{abstract}

$\operatorname{IgA}$ is the predominant antibody isotype in secretory fluids such as saliva, gastrointestinal fluids, bile, nasal and bronchial secretions, and colostrum. IgA in the secretions is predominantly dimeric and bound to the secretory piece, whereas in the serum IgA monomers prevail. Secretory IgA plays a key role in the elimination of a variety of ingested or inhaled environmental antigens and is important for the protection of the host against

Received August 19, 1993; accepted February 22, 1994.

Correspondence: Martha M. Eibl, M.D., Institute of Immunology, University of Vienna, Borschkegasse 8A, A-1090) Vienna, Austria.

${ }^{1}$ Deceased.
$\mathrm{C}$ activation. By modulating the release of mediators of inflammation such as reactive oxygen intermediates, the inflammatory response could be down-regulated at the level of the mucosal surfaces, thereby preventing the development of sequelac of an exaggerated inflammatory response potentially leading to local or systemic pathology. (Pediatr Res 36: 235-243, 1994)

$\quad$ Abbreviations
ROI, reactive oxygen intermediates
Hib, Haemophilus influenzae type b
Fc-aR, Fc receptor for IgA
MNC, mononuclear cells
DPBS, Dulbecco's PBS
PMN, polymorphonuclear leucocytes
CL, chemiluminescence
DCFH-DA, 2'7'dichlorofluorescin diacetate
DCFH, 2'7'-dichlorofluorescin
DCF, 2'7' dichlorofluorescein
PMA, phorbol 12-myristate 13-acetate
MFI, mean fluorescence intensity
PKC, protein kinase C
fMLP, n-formyl-methionyl-leucyl-phenylalanine

microbial pathogens invading by the respiratory, gastrointestinal, and urogenital tracts. IgA antibodies participate in the protection of mucosal surfaces by neutralizing bacterial toxins and viral particles and inhibiting the adherence of microbial pathogens to the epithelial cells, thus preventing colonization and penetration of mucosal surfaces by pathogenic microorganisms $(1,2)$.

Although the antiinfectious properties of $\operatorname{Ig} A$ antibodies are widely documented, the whole spectrum of mechanisms whereby $\lg \mathrm{A}$ might protect against disease is still unclear. Fc- $\alpha \mathrm{R}$ have been identified on a variety of cell types, including lymphocytes $(3,4)$, monocytes and macrophages (5-9), neutrophils $(5,6)$, and eosinophils (10). 
Recent studies have concentrated on the induction of leukocyte effector function by triggering of $\mathrm{Fc}-\alpha \mathrm{R}$. Interaction of IgA-coated particles with $\mathrm{Fc}-\alpha \mathrm{R}$ can trigger phagocytosis $(8,11-13)$ and antibody-dependent cell cytotoxicity (14). Cross-linking of Fc- $\alpha \mathrm{R}$ by $\operatorname{IgA}$ or Fc- $\alpha \mathrm{R}$ $\mathrm{MAb}$ induces the release of leukotrienes $\mathrm{C} 4$ and $\mathrm{B} 4$ and prostaglandin E2 (15) and elicits the generation of an oxidative burst $(9,16-18)$.

Although the immunomodulatory properties of $\operatorname{IgG}$ antibodies and their capacity to modulate inflammation are well documented (19), much less is known about a possible modulation of the inflammatory response by IgA. The elimination of pathogens without induction of a strong inflammatory reaction might be an important feature of the protective role of IgA against both infection and disease because an exaggerated local or systemic inflammatory reaction or immune response against antigen encountered at the level of the mucosal surfaces might be potentially harmful for the host. The production of ROI through activation of the NADPH oxidase (i.e. the respiratory burst) has long been known to play an important role in the bactericidal activity of phagocytic cells such as granulocytes and monocytes (20). However, increasing experience is accumulating that implicates human neutrophils or the generation of ROI as a mediator of tissue-destructive events in inflammatory diseases of the mucosal surfaces such as asthma bronchiale or inflammatory bowel disease (21-23). Excessive generation of ROI has also been associated with the pathophysiology of neonatal necrotizing enterocolitis, a severe inflammatory disease in low-birth-weight neonates of multifactorial cause $(24,25)$. In the present study, we addressed the question whether $\operatorname{IgA}$ might have a regulatory effect on the generation of ROI in human neutrophils and monocytes activated by stimuli known to use different recognition structures or signal transduction pathways. Our results suggest that human serum IgA not only inhibits receptor-dependent phagocyte activation but in addition might have the capacity to down-regulate the respiratory burst in human phagocytes at the level or downstream of PKC activation.

\section{METHODS}

IgA preparation. The IgA preparation was kindly provided by Dr. Y. Linnau (Immuno AG, Vienna, Austria). $\operatorname{IgA}$ was purified from serum Cohn fraction II of large plasma pools in the same way as a commercially available IgA-IgG preparation (IGABULIN, Immuno AG). The IgA-enriched preparation underwent further purification steps to obtain a final IgA product that contained more than $95 \% \operatorname{IgA}$ and no detectable IgG or IgM as examined by single radial immunodiffusion. The lyophilized Ig preparation was stored at $4^{\circ} \mathrm{C}$ until use and was dissolved in DPBS (Dulbecco's PBS with $\mathrm{Ca}^{2+}$ and $\mathrm{Mg}^{2+}$, Flow Laboratories, Irvine, UK), or CL buffer (minimum essential medium-Dulbecco for CL, Boehringer-Mannheim GmbH, Mannheim, Germany) immediately before use.
Isolation of granulocytes and mononuclear leukocytes and purification of T-enriched cells. Human MNC were isolated from heparinized peripheral blood (7.5 IU of preservative-free heparin $/ \mathrm{mL}$ ) of healthy adult volunteers (ages 18 to 65 years) of both sexes by buoyant density gradient centrifugation on Lymphoprep (Nyegaard \& Co., Oslo, Norway) (26) at $4^{\circ} \mathrm{C}$. The MNC contained in the interphase were aspirated and were washed three times in $0.9 \% \mathrm{NaCl}$ before the cells were adjusted to a concentration of $5 \times 10^{6}$ cells $/ \mathrm{mL}$ in DPBS.

Human PMN were isolated from heparinized venous blood by dextran sedimentation. The cells contained in the pellet after separation of the MNC were cleared of contaminating erythrocytes by dextran sedimentation ( $2 \%$ dextran 500, Pharmacia, Uppsala, Sweden) at $4^{\circ} \mathrm{C}$. The remaining red blood cells were removed by hypotonic lysis by resuspending the pellet in cold $\mathrm{NH}_{4} \mathrm{Cl}-$ hemolysis buffer for $10 \mathrm{~min}$ at $4^{\circ} \mathrm{C}$. After repeated washing steps the granulocytes were resuspended in DPBS at a concentration of $3.5 \times 10^{6} \mathrm{PMN} / \mathrm{mL}$. Granulocytes prepared by dextran sedimentation were $92 \pm 4 \%$ pure (mean $\pm \mathrm{SD}, n=7$ ), as determined by reading differential counts from smears.

For CL assays, human neutrophils were isolated from the buffy coat of healthy volunteer blood donors by countercurrent centrifugal elutriation with a Beckman $\mathrm{J} 2 / 21 \mathrm{M} / \mathrm{E}$ centrifuge (Beckman Instruments, Fullerton, CA). After repeated washings the granulocytes were resuspended in CL buffer at a concentration of $1 \times 10^{6}$ cells $/ \mathrm{mL}$. The resulting cell preparation contained $93 \pm$ $5 \%$ granulocytes (mean $\pm \mathrm{SD}, n=4$ ) as assessed by reading differential counts from smears. Preliminary experiments indicated that human granulocytes prepared by dextran sedimentation and granulocytes obtained by countercurrent centrifugal elutriation produced comparable levels of ROI after PMA (Sigma, St. Louis, MO) stimulation (as examined by measuring luminol-enhanced CL, data not shown).

T-enriched cells were prepared by rosetting of MNC with 2-aminoethylisothiouronium bromide-treated sheep erythrocytes after depletion of the monocytes by adherence to plastic (27). As determined by flow cytometry, T-enriched cells contained $91 \pm 11 \% \mathrm{CD} 3+\mathrm{T}$ cells, $1 \pm$ $0.4 \% \mathrm{CD} 19+\mathrm{B}$ cells, $14 \pm 9 \% \mathrm{CD} 56+$ natural killer cells (mean $\pm \mathrm{SD}, n=6$ ), and no CD14+ monocytes. Cell viability was routinely greater than $98 \%$ as determined by trypan blue dye exclusion.

Luminol-enhanced $C L$ assay. The generation of ROI in human PMN after stimulation with Hib was assessed by measuring luminol-enhanced $C L$ according to the method of Trush et al. (28). Luminol-enhanced CL has been shown to depend on the generation of ROI such as superoxide anion and $\mathrm{H}_{2} \mathrm{O}_{2}$ and on the granule enzyme myeloperoxidase that is released into the phagosome and into the extracellular environment during phagocyte activation (29). Briefly, $1 \times 10^{5} \mathrm{PMN}$ in $100 \mu \mathrm{L}$ of CL buffer (minimum essential medium-Dulbecco for CL, Boehringer-Mannheim $\mathrm{GmbH}$ ) were added to $100 \mu \mathrm{L}$ of luminol 
(Lumanol-100, Lumac, Medical Products Division/3M, St. Paul, MN; final concentration, $63 \mu \mathrm{M}), 200 \mu \mathrm{L}$ of a mixture of $\mathrm{Hib}$ (final concentration, $3 \times 10^{6} / \mathrm{mL}$ ) and IgA (final concentration ranging from $1 \mathrm{mg} / \mathrm{L}$ to $10 \mathrm{~g} / \mathrm{L}$ ), and $100 \mu \mathrm{L}$ of minimum essential medium-Dulbecco. The final volume per plastic cuvette (Luma Cuvette) was 0.5 $\mathrm{mL}$, and the ratio of bacteria to PMN was $15: 1$. Before addition to the cells, Hib and IgA were preincubated for $30 \mathrm{~min}$ at $37^{\circ} \mathrm{C}$. All substances and cells were diluted in minimum essential medium-Dulbecco. Controls included samples containing PMN and HIB, PMN and IgA, or PMN only. The resulting CL was measured over a period of $40 \mathrm{~min}$ in a bioluminescence counter (Biolumat LB 9505 C, Berthold, Wildbad, Germany). Results are given as cpm peak response or as percent inhibition of $\mathrm{CL}$ relative to the HIB-induced $\mathrm{CL}$ observed in samples containing no IgA.

Flow cytometric assay of respiratory burst. The formation of ROI in the course of the respiratory burst was assessed in human monocytes and granulocytes after stimulation with PMA or Hib by measuring the oxidation of DCFH-DA (Molecular Probes, Inc., Eugene, OR) by flow cytometry, as originally described by Bass et al. (30). This method allows for the estimation of the cumulative formation of $\mathrm{ROI}$ such as $\mathrm{H}_{2} \mathrm{O}_{2}$ in activated phagocytes (30). The nonfluorescent compound DCFH-DA diffuses across cell membranes and is trapped within the cell after deacetylation. In the presence of cellular peroxidases, the production of $\mathrm{H}_{2} \mathrm{O}_{2}$ by stimulated cells then oxidizes the intracellular DCFH, a nonfluorescent fluorescein analogue, to the highly fluorescent DCF.

Human MNC $\left(5 \times 10^{6} \mathrm{MNC} / \mathrm{mL}\right.$ in DPBS) or granulocytes isolated by dextran sedimentation $\left(3.5 \times 10^{6} / \mathrm{mL}\right.$ in DPBS) were preloaded with DCFH-DA by adding $10 \mu \mathrm{L}$ of DCFH-DA working dilution to $1 \mathrm{~mL}$ of the cell suspension [final concentration, $2.05 \mu \mathrm{mol} / \mathrm{L}(1 \mu \mathrm{g} / \mathrm{mL})$ ]. The cells were incubated for $15 \mathrm{~min}$ at $37^{\circ} \mathrm{C}$ in the dark. One hundred $\mu \mathrm{L}$ of IgA (final concentration, $1 \mathrm{mg} / \mathrm{L}$ to $10 \mathrm{~g} / \mathrm{L}$ ) and $200 \mu \mathrm{L}$ of PMA [final concentration of $1.62 \mu \mathrm{mol} / \mathrm{L}(1 \mu \mathrm{g} / \mathrm{mL})$ and 48.6 $\mathrm{nmol} / \mathrm{L}(30 \mathrm{ng} / \mathrm{mL})$ diluted in DPBS] were then added to 300 $\mu \mathrm{L}$ of DCFH-DA-preloaded cells. The mixture of PMA, IgA, and cells was further incubated in siliconized glass tubes for $25 \mathrm{~min}$ at $37^{\circ} \mathrm{C}$ in the dark before the respiratory burst was examined by flow cytometry. Preliminary experiments confirmed that the DCF-specific fluorescence of PMAstimulated monocytes increased nearly linearly during the first 20-25 min after addition of stimulus and remained essentially constant thereafter (data not shown), as has also been described for neutrophils (30). DCFH-loaded cells incubated with DPBS alone, IgA alone, or PMA alone served as controls. In some experiments, PMA and IgA were preincubated for $30 \mathrm{~min}$ at $37^{\circ} \mathrm{C}$ before addition to DCFHloaded MNC. To examine the Hib-induced respiratory burst in granulocytes by flow cytometry, we carried out the assay as described above except that $200 \mu \mathrm{L}$ of Hib (final concentration, $1 \times 10^{7} / \mathrm{mL}$ ) were added to the cells instead of PMA.

DCF-specific fluorescence resulting from oxidation of DCFH during the respiratory burst was assessed by flow cytometry using a FACScan interfaced to a Hewlett Packard computer running LYSIS software (Becton Dickinson, San Jose, CA). Monocytes within the total mononuclear leukocyte population and granulocytes isolated by dextran sedimentation were identified with a gate on the forward-scatter versus 90-degree side-scatter dot plot. Analysis of samples stained with CD14 MAb confirmed that the monocyte gate contained $>90 \%$ monocytes, and the granulocyte gate was confirmed by LeucoGate-staining (Becton Dickinson). For each flow cytometry histogram, the MFI of 5000 to 10000 cells was measured with logarithmic amplification. Because the two PMA concentrations used had a comparable effect, the results of the two concentrations were combined for statistical evaluation. Results are reported as MFI, as percent inhibition relative to the MFI of PMAstimulated samples containing no IgA, or as a stimulation index (SI) [i.e. the ratio of the MFI of cells stimulated with Hib or PMA \pm IgA (MFI experimental) to that of cells incubated in the presence of medium $\pm \operatorname{IgA}$ alone (MFI control)], calculated according to the following formula:

$$
\mathrm{SI}=\mathrm{MFI}_{\text {experimenta/ }} / \mathrm{MFI}_{\text {control }}
$$

T-cell proliferation after stimulation with PMA plus ionomycin. T-enriched cells were suspended at a concentration of $1 \times 10^{6}$ cells $/ \mathrm{mL}$ in RPMI 1640 medium (Flow Laboratories, Irvine, UK) supplemented with penicillin $(100 \mathrm{IU} / \mathrm{mL})$, streptomycin $(100 \mu \mathrm{g} / \mathrm{mL})$ and L-glutamine (2 mM, Gibco, Paisley, Scotland), and $10 \%$ heatinactivated human $\mathrm{AB}$ serum (complete medium). Cell cultures were set up in triplicate in flat-bottomed microtiter plates (Falcon 3070 Microtest III Tissue Culture Plate; Becton Dickinson Labware, Lincoln Park, NJ). Each well contained $1 \times 10^{5} \mathrm{~T}$-enriched cells in $0.1 \mathrm{~mL}$ of complete medium; $0.1 \mathrm{~mL}$ of complete medium containing the diacylglycerol analogue PMA (final concentration, $10 \mathrm{ng} / \mathrm{mL}$ ) and the calcium ionophore ionomycin (Calbiochem, San Diego, CA; final concentration, 500 $\mathrm{ng} / \mathrm{mL}$ ) were added to the cells. Cells cultured in the presence of PMA alone, ionomycin alone, or medium alone were included as controls. The cells were cultured for $5 \mathrm{~d}$ at $37^{\circ} \mathrm{C}$ in a $\mathrm{CO}_{2}$ incubator $\left(5 \% \mathrm{CO}_{2}\right.$ in humidified air). The resulting cell proliferation was assessed by measuring ${ }^{3} \mathrm{H}$-thymidine uptake. For the last $16 \mathrm{~h}$ of the 5-d incubation period, the cell cultures were pulsed with $0.2 \mu \mathrm{Ci}{ }^{3} \mathrm{H}$-thymidine $(5 \mathrm{Ci} / \mathrm{mM}$, The Radiochemical Centre, Amersham, Buckinghamshire, UK). Then the cells were harvested onto glass fiber filter strips with a semiautomatic cell harvester (Skatron, Lier, Norway), and incorporation of radioactivity was measured with a TriCarb 4640 liquid scintillation counter (Packard Instruments Corp., Downers Grove, IL). Results are presented as mean $\mathrm{dpm} \pm \mathrm{SEM}$ of the average $\mathrm{dpm}$ of individual experiments set up in triplicate.

Statistics. The statistical significance of differences between experimental and control samples was assessed by 
$t$ test for unpaired samples, the $t$ test for paired samples if appropriate, or the Mann-Whitney $U$ test (one-tailed) if the values were considered to be not normally distributed. A difference between the means of two groups was considered statistically significant at a level of $p<0.05$.

\section{RESULTS}

Effect of IgA on receptor-mediated respiratory burst in human granulocytes stimulated with unopsonized Hib. $\mathrm{Hu}-$ man neutrophils isolated by counterflow elutriation were stimulated with unopsonized heat-inactivated Hib. As assessed by measuring the luminol-enhanced CL, unopsonized Hib induced a significant release of ROI (CL, peak cpm $\times 10^{6}$ : medium, $12.5 \pm 2.0$; Hib, $78.6 \pm 8.7$; mean \pm SEM; $n=7$ ). Addition of human serum IgA to the system resulted in a dose-dependent inhibition of the Hib-induced generation of ROI (Fig. 1A). This inhibitory effect of IgA became statistically significant at concentrations as low as $10 \mathrm{mg} / \mathrm{L}$ (percent inhibition, $43 \pm 9 \%$;

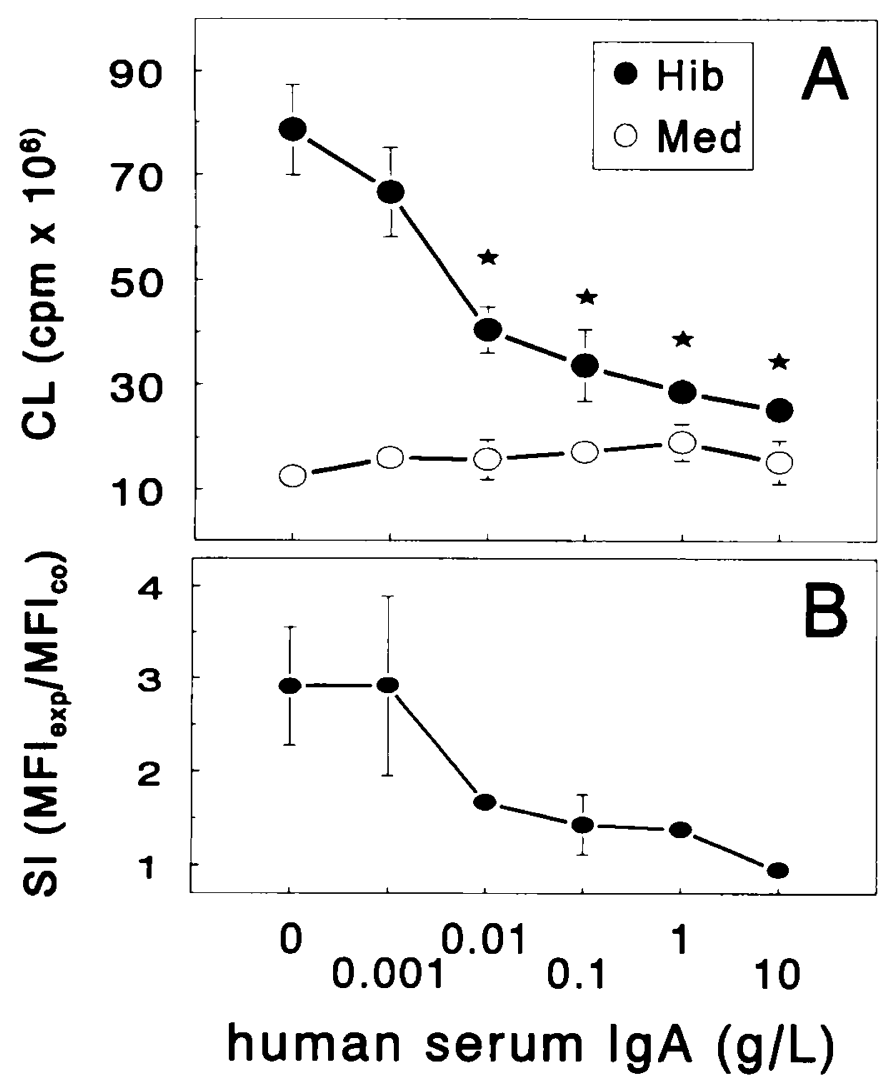

Figure 1. Human serum IgA inhibits the respiratory burst in human neutrophils activated with unopsonized Hib. Human neutrophils (PMN) isolated by counterflow elutriation $(A)$ or dextran sedimentation $(B)$ were stimulated with unopsonized heat-inactivated $\mathrm{Hib}$ in the presence of varying concentrations of IgA. PMN stimulated with Hib in the absence of IgA and PMN incubated with IgA or medium (Med) alone served as controls. $A$, Examination of the respiratory burst by measuring luminol-enhanced CL. Results are given as peak $\mathrm{cpm} \times 10^{\text {th }}$ (mean \pm SEM of seven experiments). $B$, Assessment of the production of ROI by flow cytometric measurement of DCFH oxidation. Results are given as stimulation index calculated as described in Methods (mean and range of two experiments). ${ }^{*}$, Statistically significant difference $(p<$ 0.05 ) compared with cells activated in the absence of IgA. mean $\pm \mathrm{SEM} ; n=6, t$ test, $p=0.003$ ). Increasing the concentration of $\operatorname{IgA}$ up to $10 \mathrm{~g} / \mathrm{L}$ further augmented the inhibitory effect (percent inhibition at $10 \mathrm{~g} / \mathrm{L}$ of $\operatorname{IgA}, 65 \pm$ $5 \%$; mean \pm SEM; $n=7, t$ test, $p<0.001$ ). As examined by measuring luminol-enhanced $\mathrm{CL}, \operatorname{IgA}$ alone induced no significant respiratory burst in neutrophils (Fig. 1A). An inhibitory effect of IgA on the Hib-induced respiratory burst activity in granulocytes could also be observed when the generation of ROI was examined by flow cytometric measurement of DCFH oxidation (Fig. 1B). Human granulocytes were purified from heparinized whole blood by dextran sedimentation. As estimated by calculating a stimulation index as described in the Methods section, the dose response curve of the IgA-mediated inhibition was comparable to the results obtained using the CL assay (Fig. 1).

Effect of IgA on membrane receptor-independent PMAinduced respiratory burst in human monocytes and granulocytes. The next logical question to ask was whether the inhibitory effect of $\operatorname{IgA}$ on the respiratory burst was restricted to receptor-dependent cell activation. Furthermore, we were interested whether IgA-mediated regulation of the respiratory burst observed in the granulocyte could also be found in another type of phagocytic cell, peripheral blood monocytes. CL assay of the respiratory burst in monocytes requires the preparation of a pure cell population. Multiple isolation steps (e.g. buoyant density gradient centrifugation followed by counterflow elutriation or isolation by adherence to plastic) that activate the cells to a certain extent are required to obtain a pure monocyte preparation. To minimize cellular activation associated with monocyte purification, flow cytometric assay of single monocytes within the total peripheral blood MNC presents an attractive alternative.

With flow cytometry and DCFH-DA, we investigated the effect of IgA on the respiratory burst triggered by a membrane receptor-independent stimulus, PMA, in human granulocytes and monocytes. Granulocytes enriched by dextran sedimentation and monocytes within the total MNC population were identified by their characteristic scatter profile. A representative flow cytometry histogram is depicted in Figure 2, showing that addition of $10 \mathrm{~g} / \mathrm{L}$ of $\operatorname{IgA}$ significantly decreased the PMA-induced DCF-specific fluorescence intensity in human monocytes, indicating that IgA down-modulates the PMAinduced generation of ROI during the respiratory burst. Estimation of the PMA-induced formation of ROI in monocytes by calculating a stimulation index (as described in the Methods section) indicated that an inhibitory effect of $\operatorname{IgA}$ could be observed at a concentration of $100 \mathrm{mg} / \mathrm{L}$ of IgA (data not shown). IgA also downregulated the PMA-induced respiratory burst in granulocytes, and the effect was dose dependent in both cell types (Fig. 3). A statistically significant inhibition of DCF fluorescence intensity was observed at $3 \mathrm{~g} / \mathrm{L}$ [percent inhibition, mean \pm SEM of three experiments with two PMA concentrations $(n=6)$ : granulocytes, $36 \pm 5, p=$ 0.021 ; monocytes, $51 \pm 5, p=0.033$ ]. At $10 \mathrm{~g} / \mathrm{L}, \operatorname{IgA}$ 


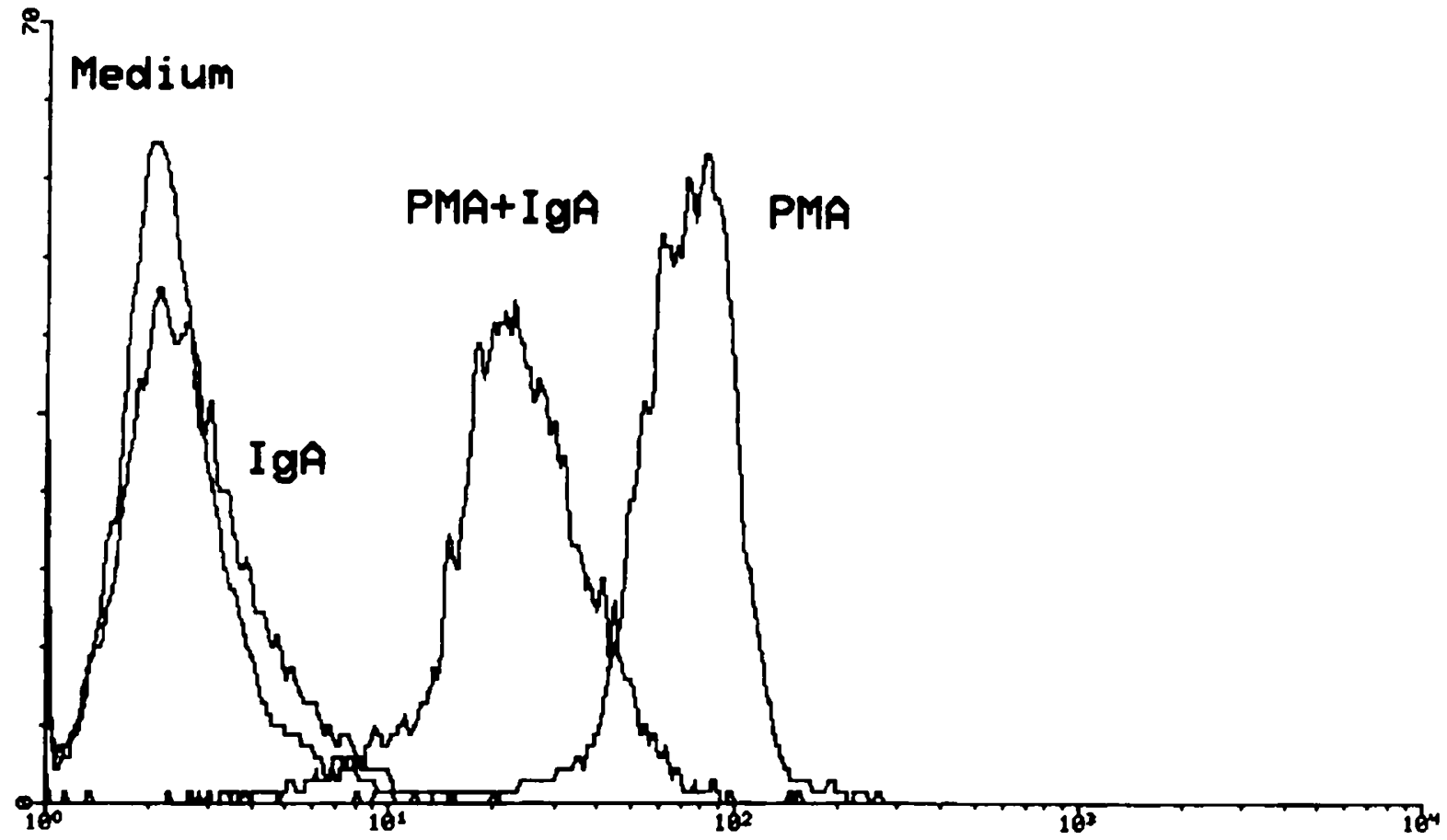

Figure 2. IgA down-regulates the PMA-induced generation of the respiratory burst in human monocytes. Human peripheral blood MNC preloaded with DCFH-DA were incubated for $25 \mathrm{~min}$ at $37^{\circ} \mathrm{C}$ in the presence of PMA $(1.62 \mu \mathrm{mol} / \mathrm{L})$, PMA and $\operatorname{IgA}(10 \mathrm{~g} / \mathrm{L})$, DPBS alone (medium), or $\mathrm{IgA}$ alone. The resulting DCF fluorescence of monocytes (5000 cells as identified by forward scatter $v s 90^{\circ}$ side-scatter gating) is shown on the horizontal axis $v s$ relative cell number on the vertical axis.

inhibited the PMA-induced generation of ROI in granulocytes by $52 \pm 5 \%$, whereas the inhibitory effect of $\operatorname{IgA}$ at this concentration was even more pronounced in monocytes because $10 \mathrm{~g} / \mathrm{L}$ of $\mathrm{IgA}$ inhibited the PMAinduced respiratory burst by $73 \pm 4 \%$ ( $t$ test, $p=0.006$ ).

High concentrations of IgA alone induced no increase in DCF-specific MFI as compared with medium (Fig. 3). Low concentrations of IgA induced only a slight increase in DCF-specific MFI in monocytes. The increase in DCFspecific MFI induced by low concentrations of $\lg A$ in granulocytes was more pronounced, although the values did not reach statistical significance.

Effect of IgA on PMA plus ionomycin-induced T-cell activation. PMA directly activates the intracellular second messenger PKC without prior triggering of a surface membrane receptor (31). IgA could have a general inhibitory effect on PMA-induced cell activation (e.g. by binding to PMA, thereby limiting the amount of free PMA available for PKC activation). However, the observed IgA-mediated inhibition of the PMA-induced respiratory burst in monocytes could not be augmented by facilitating the binding of $\operatorname{IgA}$ to PMA. When $\operatorname{IgA}$ and PMA were preincubated together for $30 \mathrm{~min}$ at $37^{\circ} \mathrm{C}$ before addition of the mixture to the MNC, the extent of inhibition of DCFH oxidation in the monocytes was comparable to that observed when IgA and PMA were added directly to the cells without preincubation [percent inhibition of PMA-induced generation of ROI (DCF-specific MFI) in the presence of $10 \mathrm{~g} / \mathrm{L}$ of $\mathrm{IgA}$, mean $\pm \mathrm{SEM}, n=5$ : with preincubation of PMA and IgA, $63 \pm 4 \%$; without preincubation, $68 \pm 4 \%]$.
To further exclude that binding of PMA to extracellular IgA leads to a decreased activation of PKC, we examined the effect of IgA on PMA plus ionomycin-induced T-cell activation. Isolated $T$ cells were activated with a suboptimal concentration of PMA [16.2 nmol/L $(10 \mathrm{ng} / \mathrm{ml})]$ plus an optimal concentration of the calcium ionophore ionomycin $[668.7 \mathrm{nmol} / \mathrm{L}(500 \mathrm{ng} / \mathrm{ml})]$, and T-cell proliferation was assessed after an incubation period of $5 \mathrm{~d}$ by measuring ${ }^{3} \mathrm{H}$-thymidine incorporation. As has been shown previously (32), ionomycin alone or PMA alone induced no T-cell activation, whereas simultaneous stimulation of the cells with PMA plus ionomycin resulted in substantial T-cell proliferation (Fig. 4). Addition of $\operatorname{IgA}(10 \mathrm{~g} / \mathrm{L})$ to the system had no effect on lymphoproliferative responses, indicating that $\operatorname{IgA}$ has no general inhibitory effect on PMA-mediated PKC activation (Fig. 4). As depicted in the inset of Figure 4, the assay system was very sensitive to detect inhibition of PMA-mediated PKC activation because a 50\% reduction of the PMA concentration reduced PMA plus ionomycin-induced T-cell proliferation to background levels.

\section{DISCUSSION}

Interaction of certain receptors on phagocytic cells with their ligands (e.g. interaction of complement receptor type 3 with opsonized bacteria or certain unopsonized particulate stimuli such as zymosan or Hib) leads to phagocytosis of the particle and to a sudden and marked activation of the oxidative metabolism, the respiratory burst $(20,33)$. Receptormediated signaling (e.g. after interaction of the chemotactic 


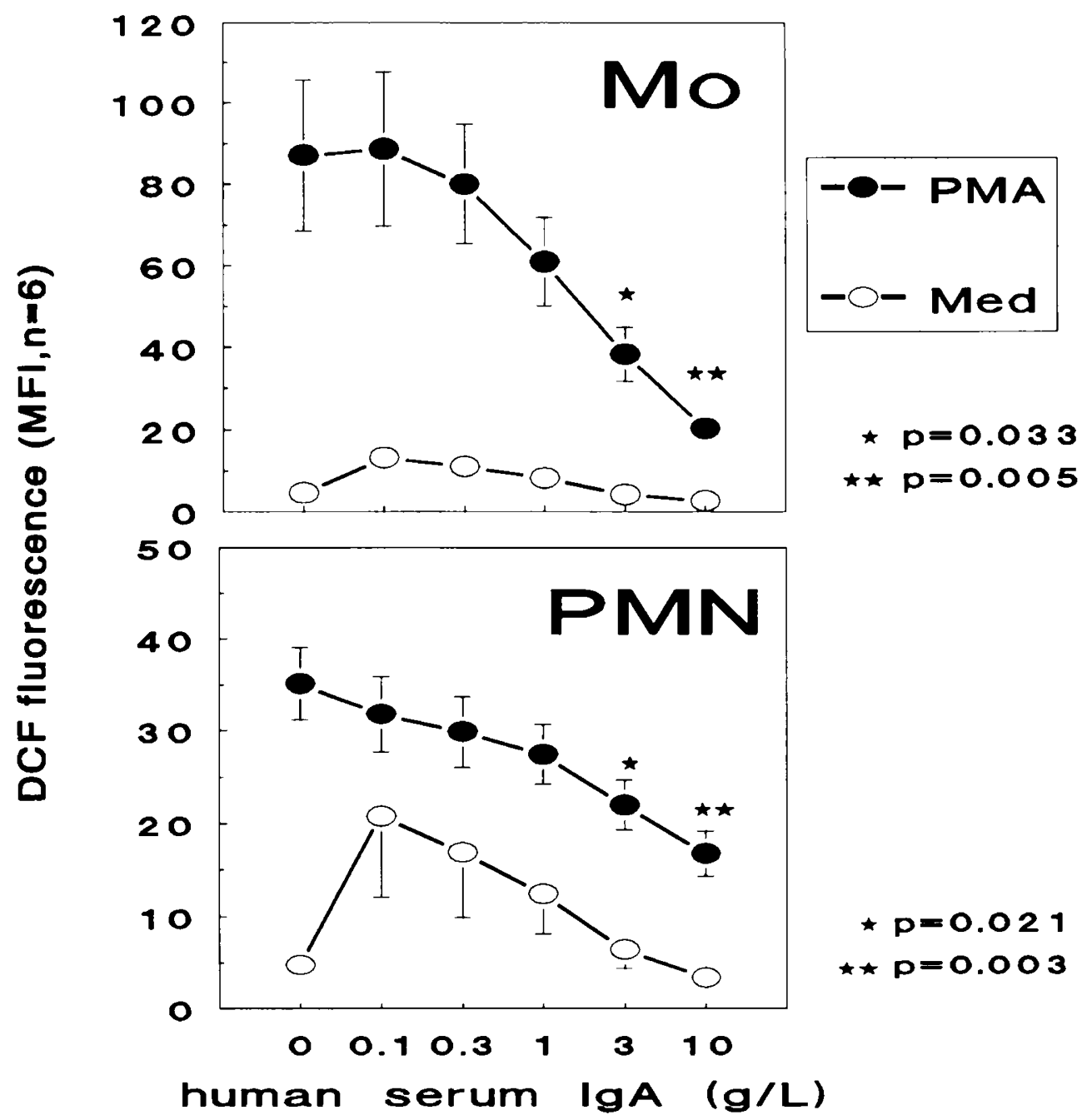

Figure 3. Human serum IgA has a dose-dependent inhibitory effect on the PMA-induced respiratory burst in human monocytes (Mo) and granulocytes (PMN). Human granulocytes or MNC were stimulated with PMA $(48.6 \mathrm{nmol} / \mathrm{L}$ or $1.62 \mu \mathrm{mol} / \mathrm{L})$ in the presence of varying concentrations of IgA. Cells incubated in the presence of PMA, IgA, or DPBS (medium) alone served as controls. The resulting DCF-specific fluorescence is given as MFI [mean \pm SEM of three experiments, each performed with two PMA concentrations $(n=6)$ ]. Both ${ }^{*}$ and ${ }^{* *}$ denote statistically significant differences compared with cells activated in the absence of $\operatorname{lgA}$.

peptide fMLP with its receptor) involves the generation of second messengers such as inositol phosphates and diacylglycerol and an increase in the levels of intracellular free $\mathrm{Ca}^{++}$before PKC is activated, which in turn is followed by activation of the NADPH oxidase complex (33). In the course of the respiratory burst, phagocytic cells generate superoxide anion (reactive oxygen radical, $\mathrm{O}_{2}{ }^{-}$) and derived reactive oxygen products such as $\mathrm{H}_{2} \mathrm{O}_{2}$ and the hydroxyl radical, collectively termed ROI. Together with the release of the contents of cytoplasmic granules (e.g. myeloperoxidase) into the endosomal vacuole (containing the engulfed bacterium), the respiratory burst results in the killing and digestion of the phagocytosed bacteria. In addition, the release of ROI also participates in the development of the inflammatory reaction by mediating tissue-destructive events at the site of inflammation (21-23).

The results presented in this article show that human IgA (in concentrations as low as $10 \mathrm{mg} / \mathrm{L}$ ) significantly inhibits the respiratory burst in human granulocytes (PMN) activated by a particulate stimulus, unopsonized heat-inactivated Hib. The inhibitory effect of $\operatorname{IgA}$ on Hib-induced PMN activation was demonstrated by examination of luminol-enhanced CL (dependent on the production of ROI and degranulation) and measurement of DCFH oxidation with flow cytometry (a method that allows for measurement of the cumulative production of ROI such as $\mathrm{H}_{2} \mathrm{O}_{2}$ ). Activation of PMN with $\mathrm{Hib}$ is mediated through triggering of surface membrane receptors such as the complement receptor type 3 , which has a binding site for lipopolysaccharide expressed on gramnegative bacteria such as Hib (34). Several previous articles reported that interaction of $\lg A$ with human granulocytes can result in inhibition of receptor-dependent activation of cell functions such as chemotaxis, phagocytosis, and generation of the respiratory burst (35-38). However, the mechanism of this suppression is still unclear. Previous studies showed that inhibition of receptor-dependent PMN activation was primarily mediated by IgA polymers, was dependent on the Fc portion of IgA, and was dependent on binding of IgA to the cell but 
not to the stimulus, suggesting that interaction of $\operatorname{IgA}$ with the Fc- $\alpha \mathrm{R}$ was involved in inhibition of cell activation $(35,37,38)$. It has been proposed that the cell-bound IgA might interfere with stimulus-receptor interaction. In fact, binding of ligand to the Fc- $\gamma \mathrm{R}$ could be inhibited by $\operatorname{IgA}$ bound to the PMN surface $(35,36)$, and $\operatorname{IgA}$ also blocked the binding of MAb to the neutrophil complement receptor type 1 (36). However, blockade of ligandreceptor interaction might not be a sufficient explanation for the capacity of $\operatorname{IgA}$ to down-modulate neutrophil activation. Inhibition of PMN chemotaxis by $\operatorname{IgA}$ was independent of the type of receptor triggered to stimulate the cells because IgA paraproteins have been shown to inhibit human neutrophil activation by a variety of chemotactic stimuli, including casein, Escherichia coliderived chemotactic factors, complement component C5a, serum chemotactic components, and $\operatorname{fMLP}(37,38)$. Furthermore, IgA paraproteins inhibited the $\mathrm{CL}$ response of neutrophils to fMLP (38), whereas more recent studies showed that $\operatorname{IgA}$ does not significantly interfere with binding of fMLP to neutrophils (39). These findings suggested to us that IgA might inhibit leukocyte activation without influencing receptor-ligand interaction.

The respiratory burst can be induced by activation of phagocytes with membrane receptor-independent stimuli such as PMA. Phorbol diesters such as PMA mimic the action of the intracellular second messenger diacylglycerol, a physiologic activator of PKC, by binding directly to $\mathrm{PKC}$ with high affinity, resulting in the activation of the respiratory burst without triggering a surface membrane receptor $(31,33)$. Our data show that in addition to inhibition of receptor-dependent neutrophil activation, IgA also has the capacity to inhibit the generation of ROI such as $\mathrm{H}_{2} \mathrm{O}_{2}$ (as examined by flow cytometric measurement of DCFH oxidation) in human neutrophils and monocytes activated with PMA. A possible explanation for this inhibitory effect could be competitive blockade of PKC activation by binding of PMA to IgA. However, our data provide the following evidence that makes this hypothesis unlikely. Preincubation of IgA with PMA before addition to the monocytes, which would facilitate binding of PMA to IgA, did not augment the inhibitory effect of IgA. Furthermore, IgA did not inhibit PMA-induced activation of PKC in isolated human T cells. The synergistic combination of PKC activation by phorbol esters and elevation of cytosolic calcium by calcium ionophores is required to induce receptor-independent activation and proliferation of isolated T lymphocytes (32). Even at high concentrations $(10 \mathrm{~g} / \mathrm{L})$, which clearly inhibited the PMAinduced respiratory burst in monocytes and granulocytes, IgA had no suppressive effect on T-cell proliferation after stimulation with PMA plus ionomycin. Although an optimal concentration of ionomycin was used in our system, the concentration of PMA used was clearly suboptimal because reduction of the PMA concentration by $50 \%$ completely abrogated PMA plus ionomycin-induced $\mathrm{T}$-cell proliferation. Thus, we think that our system should have been sensitive enough to detect

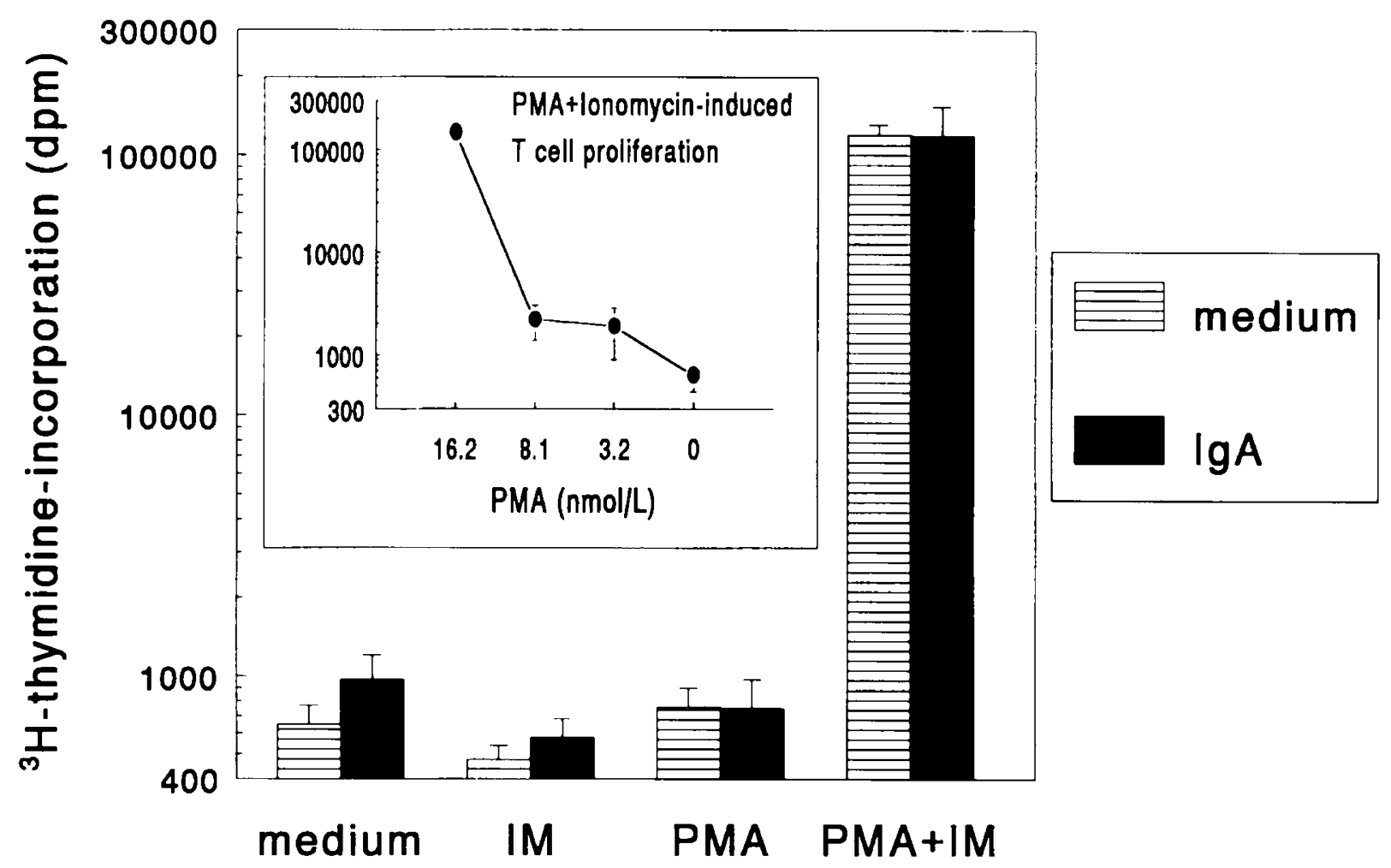

Figure 4. IgA does not inhibit interaction of PMA with PKC because it has no effect on PMA plus ionomycin-induced T-cell activation. Human $T$ cells were stimulated for $5 \mathrm{~d}$ with PMA $(16.2 \mathrm{nmol} / \mathrm{L})$ plus ionomycin $(668.7 \mathrm{nmol} / \mathrm{L})$ in the presence or absence (medium control) of $\mathrm{IgA}(10 \mathrm{~g} / \mathrm{L})$. The resulting $\mathrm{T}$-cell proliferation was assessed by measuring ${ }^{3} \mathrm{H}$-thymidine incorporation, and the results are given as dpm (mean $\pm \mathrm{SEM}$ of seven individual experiments). Inset shows stimulation of $\mathrm{T}$ cells with ionomycin $(668.7 \mathrm{nmol} / \mathrm{L})$ plus varying concentrations of $\mathrm{PMA}$. 
any extracellular binding of PMA to IgA that would result in decreased PKC activation.

The results presented in this article therefore suggest that inhibition at the level of receptor-ligand interaction may not be the only explanation for a suppressive effect of IgA on phagocyte activation. More likely, IgA may directly modulate signaling in the course of phagocyte activation, probably at the level or downstream of PKC activation by induction of a negative signal. Several studies have demonstrated that triggering of Fc- $\alpha \mathrm{R}$ on phagocytic cells by IgA-coated particles, polymeric IgA, or Fc- $\alpha$ R-MAb can induce a positive signal in the cells that triggers phagocytosis $(8,11-13)$, antibody-dependent cell cytotoxicity (14), the release of leukotrienes C4 and B4, prostaglandin E2 release (15), and the generation of an oxidative burst $(9,16-18)$. In our experiments, low concentrations of serum IgA alone induced a slight increase in DCFH oxidation in granulocytes and also slightly increased DCF fluorescence in monocytes. Although the stimulation of ROI generation was too weak to reach statistical significance, these results might suggest a weak positive signal rather than just an absence of inhibition, indicating that $\operatorname{IgA}$ in our system does not exclusively deliver an "off" signal in phagocytic cells. It might depend on the type of cell, on its state of activation, or on possible concomitant signals whether IgA triggers positive or negative signaling. A previous study provided additional evidence along these lines by showing that interaction of human IgA with the Fc- $\alpha$ R on human PMN stimulated chemotaxis and increased PMN migration in response to suboptimal concentrations of fMLP, whereas $\operatorname{IgA}$ decreased PMN responses to optimal fMLPconcentrations (39).

The inhibitory effect of IgA on the generation of ROI could be observed over a wide concentration range (10 $\mathrm{mg} / \mathrm{L}$ to $10 \mathrm{~g} / \mathrm{L}$ ). Taking into consideration that the $\operatorname{IgA}$ concentration in human secretions varies between 60 $\mathrm{mg} / \mathrm{L}$ and $12 \mathrm{~g} / \mathrm{L}(2,40)$, it could be speculated that the regulatory effect of IgA on the production of mediators of inflammation such as ROI documented in the present article is of biologic relevance over a wide concentration range at different sites and in different clinical situations. The generation of reactive oxygen metabolites by phagocytic cells has been implicated in the pathophysiologic process of tissue-destructive events at the level of the mucosal surfaces in inflammatory diseases such as asthma bronchiale and inflammatory bowel disease (2123). Excessive generation of mediators of inflammation such as ROI and inflammatory cytokines such as tumor necrosis factor- $\alpha$ has also been associated with the pathophysiology of neonatal necrotizing enterocolitis, an important gastrointestinal disease in low-birth-weight infants $(24,25,41,42)$. Blockade of the action of reactive oxygen radicals by superoxide dismutase totally prevented intestinal injury in an animal model of the disease (25). This finding is especially interesting in view of the IgA-mediated down-regulation of the generation of ROI presented in this article because a controlled clinical trial has demonstrated that oral IgA-IgG treatment is an effective prophylaxis of necrotizing enterocolitis in lowbirth-weight infants (43). Recent studies performed in our laboratory showed that human IgA down-regulates both the induction and the release of inflammatory cytokines (tumor necrosis factor- $\alpha$, interleukin-6) in human monocytes (44). By modulating the release of inflammatory mediators such as ROI or inflammatory cytokines, $\operatorname{IgA}$ could interfere with the development of sequelae of acute or chronic inflammation initiated by microbial pathogens or their toxins at the level of the mucosal surfaces, thereby preventing local and systemic pathology.

\section{REFERENCES}

1. Brandtzaeg $\mathbf{P} 1992$ Humoral immune response patterns of human mucosae: induction and relation to bacterial respiratory tract infections. J Infect Dis 165(suppl 1):167-176

2. Kerr MA 1990 The structure and function of human IgA. Biochem J 271:285296

3. Lum LG, Muchmore AV, Keren D, Decker J, Koski 1, Strober W, Blaese RM 1979 A receptor for IgA on human T lymphocytes. J Immunol 122:65-69

4. Gupta S, Platsoucas CD, Good RA 1979 Receptors for IgA on a subpopulation of human B lymphocytes. Proc Natl Acad Sci USA 76:4025-4029

5. Fanger MW, Shen L, Pugh J, Bernier GM 1980 Subpopulations of human peripheral granulocytes and monocytes express receptors for IgA. Proc Natl Acad Sci USA 77:3640-3644

6. Fanger MW, Goldstine SN, Shen L 1983 Cytofluorographic analysis of receptors for IgA on human polymorphonuclear cells and monocytes and the correlation of receptor expression with phagocytosis. Mol Immunol 20:10191027

7. Gauldie J, Richards C, Lamontagne L $1983 \mathrm{Fc}$ receptors for IgA and other immunoglobulins on resident and activated alveolar macrophages. Mol Immunol 20:1029-1037

8. Maliszewski CR, Shen L, Fanger MW 1985 The expression of receptors for IgA on human monocytes and calcitriol-treated HL-60 cells. J Immunol 135:3878-3881

9. Robinson G, Volovitz B, Passwell JH 1991 Identification of a secretory IgA receptor on breast-milk macrophages: evidence for specific activation via these receptors. Pediatr Res 29:429-434

10. Abu-Ghazaleh RI, Fujisawa T, Mestecky J, Kyle RA, Gleich GJ 1989 IgAinduced eosinophil degranulation. J Immunol 142:2393-2400

11. Shen L, Maliszewski CR, Rigby WF, Fanger MW 1986 IgA-mediated effector function of HL-60 cells following treatment with calcitriol. Mol Immunol 23:611-618

12. Yeaman GR, Kerr MA 1987 Opsonization of yeast by human serum IgA anti-mannan antibodies and phagocytosis by human polymorphonuclear leukocytes. Clin Exp Immunol 68:200-208

13. Weisbart RH, Kacena A, Schuh A, Golde DW 1988 GM-CSF induces human neutrophil-mediated phagocytosis by an IgA Fc receptor activation mechanism. Nature 332:647-648

14. Shen L, Fanger MW 1981 Secretory $\operatorname{lgA}$ antibodies synergize with $\operatorname{lgG}$ in promoting ADCC by human polymorphonuclear cells, monocytes, and lymphocytes. Immunology 59:75-81

15. Ferreri NR, Howland WC, Spiegelberg HL 1986 Release of leukotrienes C4 and $B 4$ and prostaglandin E2 from human monocytes stimulated with aggregated IgG, IgA, and IgE. J Immunol 136:4188-4193

16. Shen L, Lasser R, Fanger MW 1989 My 43, a monoclonal antibody that reacts with human myeloid cells inhibits monocyte IgA binding and triggers function. J Immunol 143:4117-4122

17. Shen $L 1992$ A monoclonal antibody specific for immunoglobulin A receptor triggers polymorphonuclear neutrophil superoxide release. J Leukoc Biol 51:373-378

18. Shen L, Collins J 1989 Monocyte superoxide secretion triggered by human IgA. Immunology 68:491-496

19. Dwyer JM 1992 Manipulating the immune system with immune globulin. $N$ Engl J Med 326:107-116

20. Babior BM 1978 Oxygen-dependent microbial killing by phagocytes. N Engl J Med 298:659-668

21. Malech HL, Gallin JI 1987 Neutrophils in human diseases. N Engl J Med 317:687-694

22. Henson PM, Johnston Jr RB 1987 Tissue injury in inflammation: oxidants, proteinases, and cationic proteins. J Clin Invest 79:669-674

23. Weiss SJ 1989 Tissue destruction by neutrophils. N Engl J Med 320:365-376

24. Clark DA, Fornabaio DM, McNeill H, Mullane KM, Caravella SJ, Miller MJ 1988 Contribution of oxygen-derived free radicals to experimental necrotizing enterocolitis. Am J Pathol 130:537-542

25. Miller MJ, McNeill H, Mullane KM, Caravella SJ, Clark DA 1988 SOD prevents damage and attenuates eicosanoid release in a rabbit model of necrotizing enterocolitis. Am J Physiol 255:G556-G565 
26. Boyum A 1968 Isolation of mononuclear cells and granulocytes from human blood. Scand J Lab Invest 21(suppl 97):77-89

27. Pellegrino MA, Ferrone S, Theofilopoulos AN 1976 Isolation of human T and B lymphocytes by rosette formation with 2 -aminoethylisothiouronium bromide (AET)-treated sheep red blood cells and with monkey red blood cells. J Immunol Meth 11:273-279

28. Trush MA, Wilson ME, Van Dyke K 1978 The generation of chemiluminescence (CL) by phagocytic cells. In: DeLuca MA (ed) Methods in Enzymology, Vol 57. Academic Press, New York, pp 462-494

29. DeChatelet LR, Long GD, Shirley PS, Bass DA, Thomas MJ, Henderson FW, Cohen MS 1982 Mechanism of the luminol-dependent chemiluminescence of human neutrophils. J Immunol 129:1589-1593

30. Bass DA, Parce JW, DeChatelet LR, Szeda P, Seeds MC, Thomas M 1983 Flow cytometric studies of oxidative product formation by neutrophils: graded response to membrane stimulation. J Immunol 130:1910-1917

31. Castagna M, Takai Y, Kaibuchi K, Sano K, Kikkawa U, Nishizuka Y 1982 Direct activation of calcium-activated, phospholipid-dependent protein kinase by tumor-promoting phorbol esters. J Biol Chem 257:7847-7851

32. Kumagai N, Benedict SH, Mills GB, Gelfand EW 1987 Requirements for the simultaneous presence of phorbol esters and calcium ionophores in the expression of human $T$ lymphocyte proliferation-related genes. J Immunol 139:1393-1399

33. Morel F, Doussiere J, Vignais PV 1991 The superoxide-generating oxidase of phagocytic cells. Physiologic, molecular and pathological aspects. Eur J Biochem 201:523-546

34. Wright SD, Levin SM, Jong MTC, Chad Z, Kabbash LG 1989 CR3 (CD11b/ CD18) express one binding site for Arg-Gly-Asp containing peptides and a second site for bacterial lipopolysaccharide. J Exp Med 169:175-183
35. Wilton JMA 1978 Suppression by IgA of lgG-mediated phagocytosis by human polymorphonuclear leucocytes. Clin Exp Immunol 34:42.3-428

36. Saito K, Kato C, Katsuragi H, Komatsuzaki A 1991 IgA-mediated inhibition of human leukocyte function by interference with $\mathrm{Fcr}$ and $\mathrm{C} 3 \mathrm{~b}$ receptors. Immunology 74:99-106

37. Van Epps DE, Williams RC 1976 Suppression of leukocyte chemotaxis by human IgA myeloma components. J Exp Med 144:1227-1242

38. Van Epps DE, Brown SL 1981 Inhibition of formylmethionyl-leucylphenylalanine-stimulated neutrophil chemiluminescence by human immunoglobulin A paraproteins. Infect Immun 34:864-870)

39. Sibille Y, Delacroix DL, Merill WW, Chatelain B, Vaerman JP 1987 IgAinduced chemokinesis of human polymorphonuclear neutrophils: requirement of their Fc-alpha receptor. Mol Immunol 24:551-559

40. Delacroix DL, Marchandise FX, Francis C, Sibille Y 1985 Alpha-2 macroglobulin, monomeric and polymeric immunoglobulin $A$, and immunoglobulin $\mathbf{M}$ in bronchoalveolar lavage. Am Rev Respir Dis 132:829_-835

41. Caplan MS, Sun X-M, Hsueh W, Hageman JR 1990 Role of platelet activating factor and tumor necrosis factor-alpha in neonatal necrotizing enterocolitis. $J$ Pediatr 116:960)-964

42. Caplan MS, Hsueh W 1990 Necrotizing enterocolitis: role of platelet activating factor, endotoxin and tumor necrosis factor. J Pediatr 117:S47-S51

43. Eibl MM, Wolf HM, Fürnkranz H, Rosenkranz A 1988 Prevention of necrotizing enterocolitis in low-birth-weight infants by IgA-IgG feeding. $\mathrm{N}$ Engl J Med 319:1-7

44. Wolf HM, Fischer MB, Pühringer H, Samstag A, Vogel E, Eibl MM 1994 Human serum IgA downregulates the release of inflammatory cytokines (tumor necrosis factor- $\alpha$, interleukin-6) in human monocytes. Blood 83:12781288 